Wirtschaftswissenschaftliches Zentrum (WWZ) der Universität Basel

$\mathrm{WW} \mid \mathrm{Z}$

December 2011

\title{
Director Characteristics and Firm Performance
}


The Authors:

Pascal Gantenbein, Prof. Dr.

Faculty of Business and Economics

Finance Management

University of Basel

Peter Merian-Weg 6

CH - 4002 Basel

Switzerland

phone: +41(0)61 2672459

pascal.gantenbein@unibas.ch

\section{Christophe Volonté, Assistent}

Faculty of Business and Economics

Finance Management

University of Basel

Peter Merian-Weg 6

CH - 4002 Basel

Switzerland

phone: +41(0)61 2672462

christophe.volonte@unibas.ch

A publication of the Faculty of Business and Economics, University of Basel.

(c) WWZ Forum 2011 and the author(s). Reproduction for other purposes than the personal use needs the permission of the author(s).

\section{Contact:}

WWZ Forum | Peter Merian-Weg 6 | CH-4002 Basel | forum-wwz@unibas.ch | www.wwz.unibas.ch 


\title{
Director Characteristics and Firm Performance*
}

\author{
Pascal Gantenbein ${ }^{\dagger} \quad$ Christophe Volonté ${ }^{\ddagger \S}$ \\ University of Basel \\ Faculty of Business and Economics \\ Working Paper \\ December 22, 2011
}

\begin{abstract}
The traditional methodology examining optimal boards relates a simple board variable (e.g., independence or board demography) to firm performance, however, ignoring other board characteristics. This paper investigates how the education and business experience of directors affect firm performance. The sample consists of 1,574 directorships from 224 listed firms in Switzerland. Using OLS and including control variables, the results show that graduates of minor Swiss universities are negatively related to Tobin's $\mathrm{Q}$, and industrial knowledge and Tobin's $\mathrm{Q}$ are negatively correlated if the firm has more divisions. In addition, director fixed effects (or unobserved characteristics) are significant, but improve the explanatory power of the models only by 5 percent.
\end{abstract}

JEL-Classification: G30; G34; G38

Keywords: Corporate governance; Board of directors; Director characteristics; Education and business experience

\footnotetext{
${ }^{*}$ The authors acknowledge the research grant by the Föderverein WWZ (B-119). We thank Hermione Miller-Moser for her editorial assistance.

${ }^{\dagger}$ Prof. Dr. Pascal Gantenbein is head of the Henri B. Meier Department of Financial Management, University of Basel, Switzerland.

${ }^{\ddagger}$ Christophe Volonté is assistant at the Henri B. Meier Department of Financial Management, University of Basel, Switzerland.

${ }^{\S}$ Corresponding author. Christophe Volonté, Faculty of Business and Economics, Peter MerianWeg 6, CH-4002 Basel, Switzerland, Tel: +41-61-267-24-62; fax: +41-61-267-24-63; e-mail: christophe.volonte@unibas.ch.
} 
The board of directors assumes an important task in modern corporations. The primary responsibility of the board is to monitor the management on the shareholders' behalf. In addition, the board advises the management and has decision power. This power includes setting the firm's strategy and executive compensation, appointing the top management and nominating new directors. Since the board of directors is vested with the responsibility of ensuring that the shareholders' money is not wasted, shareholders ought to have a serious interest in ensuring that the board is staffed with well educated and experienced directors.

Accordingly, surveys conducted by consultancy firms frequently mention "hard" and "soft" personal profile factors of directors to be important for board efficiency. Such factors include experience, know-how, and education, but also integrity, leadership or credibility (KPMG, 2001). Similar reports posit the importance of expertise such as financial, industrial or international experience (Spencer Stuart, 2010).

Firms themselves, or their boards, precisely specify the profile requirements they expect of their directors. For instance, Airesis, a sporting brands holding, explicitly states in their 2008 annual report that the board must consist of at least one member with board experience in listed corporations, one member with a legal background, and one member with financial knowledge. Additionally, they should bring such skills to the board that facilitate interactive decision-making.

Last but not least, regulations influence the composition of boards, as well. For instance, the U.S. Sarbanes-Oxley Act (SOX) of 2002 proposes every board to create an independent audit committee composed of financial experts (Linck et al., 2009). ${ }^{1}$

Furthermore, today's boards are subject more than ever to duties of diligence owing to the increasing threat of litigation. Legal compliance issues require modern board members to possess the requisite legal expertise.

In contrast to rather journalistic surveys, academic studies very rarely tackle director characteristics from the viewpoint of specialist knowledge (see Adams et al., 2010). Directors are typically divided into groups according to their independence from the firm. Usually, academic research identifies executive directors as being insiders and non-management directors as being outsiders. However, this ignores the fact that the two groups of directors may require different skills in order to execute their duties adequately. For instance, Fama and Jensen (1983) underline the importance of outside directors with specific expertise (e.g., in finance, corporate law or industrial technology). Hence, outsiders do not all have one and the same purpose on the board.

\footnotetext{
${ }^{1}$ See Section 301(m)(3)(A): "In general - Each member of the audit committee of the issuer shall be a member of the board of directors of the issuer, and shall otherwise be independent". And SOX Section 407(a): "Rules Defining 'Financial Expert'. The Commission shall issue rules, as necessary or appropriate in the public interest and consistent with the protection of investors, to require each issuer, together with periodic reports required pursuant to sections 13(a) and 15(d) of the Securities Exchange Act of 1934, to disclose whether or not, and if not, the reasons therefor, the audit committee of that issuer is comprised of at least 1 member who is a financial expert, as such term is defined by the Commission."
} 
More recent studies examine the impact of board demography (or board diversity) on firm performance or behavior, and there are also studies specifically addressing gender or ethnicity issues; yet, all are silent about the real value of the personal expertise that directors bring to the board. The question of personal profile needs to be addressed, because the performance benefits from career specifics are not directly correlated with demographics (i.e., females or foreigners). As an illustration, the management researchers Hillman et al. (2002) show that "community influentials" are more likely to be females or African-American. ${ }^{2}$ Similarly, sociologists Zeng and Xie (2004) find evidence that U.S. employees educated abroad earn less than Americans or foreigners educated in the United States.

These two examples demonstrate that the omission of certain attributes, such as skill and experience, causes problems when assessing the aptitude of various profiles for specific posts. Specifically, ethnicity and gender may affect firm performance indirectly via other associated characteristics. Factors such as place of education (i.e., domestic or abroad) and experience (i.e., "community influentials" or "business experts") may be more relevant than demographic attributes in explaining firm performance. Hence, if such issues are omitted, the results of empirical investigations may lead to false interpretations, because more important features are left out. In terms of econometric quality, omitted factors are completely absorbed in the error term leading to endogeneity problems if one does not describe directors more precisely.

Numerous research results have been published on board structures since the $1970 \mathrm{~s}$. These studies examine the determinants of board structure, the firm behavior affected by board structure, and lastly the influence of the board on firm performance. Nevertheless, there is no conclusive evidence determining what constitutes an optimal board composition. One reason might be that board composition has been examined using broad classifications such as board independence or demography. However, features relating to skills may be more important in studying board effectiveness. Unfortunately, studies examining the effect of education or business experience on firm performance are rare.

An explanation of why the personal characteristics of directors are mostly ignored may be due to the absence of theoretical foundations for explaining the impact that particular directors have on firm performance or company behavior. As an example, in contrast to independent non-executive directors, it is difficult to develop a rationale promoting more university graduates on boards. Additionally, empirical studies do not often address director skills, because detailed data of these characteristics is not readily avail-

\footnotetext{
${ }^{2}$ In an earlier study, Hillman et al. (2000) classify board members skill-wise into three categories with specific board roles. The first group, "business experts" have executive experience as CEOs or as officers of large corporations. The second group, "support specialists" provide particular services to the boards; e.g., legal advice or financial expertise. And the final category includes politicians and university professors. This group has no specialized business background, but influences society and opinion-making. Such directors are denominated "community influentials" (Baysinger and Butler (1985) apply similar classifications).
} 
able. Personal factors (e.g., talent) are either not observable or difficult to proxy.

This paper contributes to the literature in one important way. The study sheds light on how education (e.g., university graduates) and the professional background (e.g., industrial knowledge) of directors are related to firm performance in Swiss firms. Education and professional experience are often mentioned by surveys and consultancy firms, but rarely investigated by academic papers. We employ 17 variables to describe the educational background and 4 variables defining professional experience. Data was handcollected from 224 annual reports in 2008 which comprise 1,574 directors. Furthermore, we use fixed effects to examine whether the unobserved heterogeneity of directors is an important factor in explaining firm performance.

\section{Literature Review}

The quasi non-existence of empirical studies on the education and business experience of board members leaves us with a narrow literature review. Our review is restricted to studies that address directors with financial expertise, especially bankers. To our knowledge, no previous study investigates the relationship between education and business experience (except for financial know-how), and firm performance. Financial know-how is one of many variables applied in this paper. Moreover, ever since the introduction of SOX, financially literate directors are legally requested on audit committees, and some countries historically have had an important banking-influence in their corporate governance (see La Porta et al., 1998). To illustrate the issue, commercial bankers representing banking interests are encountered more frequently in Germany or Japan than in the United States, especially in large and stable firms (Kroszner and Strahan, 2001). In 1995, German financial institutions held 19 percent of all directorships (Schroder and Schrader, 1997).

Several empirical studies investigated the impact of directors with financial knowhow on firm policy and on stock prices. Bankers seem to affect firm policy, e.g., they increase external funding if the firm has poor forecasts, but good credit ratings or tend to decrease the debt ratio if the director is from a lending bank (see Güner et al., 2008; Byrd and Mizruchi, 2005). Bankers are also more likely to be present on specific boards. Ramirez (1995) demonstrates that firms associated with J.P. Morgan in the United States are financially less constrained. Such associations usually implied that someone from J.P. Morgan would assume a seat on the board and thus monitor its client. Jeanjean and Stolowy (2009) indicate that the board and ownership structure is related to the proportion of bankers on French boards. Finally, Dittmann et al. (2010) show that bankers are negatively related to firm value in non-financial corporations in Germany. Furthermore, they detect that bankers do not perform a monitoring role neither in their own inter- 
est as debtholders nor as shareholders. Also, bankers do not seem to provide financial expertise for firms in financial distress. In contrast, they find evidence that bankers promote financial services and increase borrowing. These directors also seek appointments to larger boards that facilitate networking.

In brief, the benefits of financial expertise on a board is related to the intentions of the appointed directors. They might face conflicts of interests in their board capacity, especially where equity stakes and debt are concerned. For instance, stock prices react positively if an independent director with financial expertise is appointed to an audit committee of a firm with strong corporate governance (DeFond et al., 2005). Thus, the firm's environment is important in addressing the effect of professional expertise or education on firm performance.

\section{Data Description and Definition of Variables}

One of the reasons why most empirical studies on the composition of the board of directors are restricted to simple board characteristics is data availability. Collecting more detailed information on directors is time consuming. In this study, information on 1,574 directorships from 224 annual reports in 2008 is hand-collected for all firms listed at the Swiss stock exchange. This is six years after the Swiss Code of Best Practice for Corporate Governance (Economiesuisse, 2008) and the Directive on Information relating to Corporate Governance (SIX Exchange, 2008) were introduced. These standards led to improved information disclosure about each director in the annual report (e.g., curriculum vitae). This advance enabled us to obtain the detailed data required for our study.

\subsection{Dependent Variable: Tobin's Q}

Firm performance is measured using Tobin's $Q(Q) . Q$ is calculated as the ratio of the market value of equity plus book value of total debt to the book value of total assets. The study uses all classes of equity, including non-listed equity. The equity price is the mean value calculated on the basis of a 30 -trading day window around the last trading day in 2007 multiplied by the number of the respective securities. ${ }^{3}$ The market value of non-listed equity of listed companies is derived from the mean stock prices adjusted to the nominal value. The market value, based on the stock prices, can be seen as the risk-adjusted present value of all future cash flows. The gap between the market value and the book value can consist of intangible assets which, among other factors, may also mirror the ability of the board of directors.

\footnotetext{
${ }^{3}$ The unadjusted price (UP) in Thomson Reuters Datastream.
} 


\subsection{Education Variables}

The first group of director characteristics is related to its educational background. Our assessment of educational background is limited to higher education, because this is what usually is disclosed in annual reports. First of all, the academic degree is assessed: a professorial status is denoted $P R$, a doctoral degree ( $\mathrm{Ph}$.D.) is denoted $D R$, a master of business administration degree or equivalent is denoted $M B A$, a university degree is denoted $U N I$, and another higher education degree is denoted $F H$ ( 0 is the reference group for no higher education). ${ }^{4}$ Each variable measures the fraction of directors on the board with a specific feature.

Furthermore, university graduates are split into four major fields of study: business and economics (ECO), law ( $L A W)$, natural sciences (NAT), and technical sciences (TEC) ( 0 is another field of studies or none).

Finally, the provenance of the degree is considered. The alma mater of the directors is collected for six major Universities in Switzerland: the University of Basel $(B S)$, the University of Berne $(B E)$, the Federal Institute of Technology in Zurich $(E T H)$, the University of Geneva $(G E)$, the University of St. Gallen $(S G)^{5}$, and the University of Zurich $(\mathrm{ZH})$ are included. Moreover, education at another Swiss university, which comparatively few directors attended, is denoted $O T H U^{6}$ and a foreign university is denoted FOU (0 is for no university degree or not defined).

\subsection{Business Experience Variables}

The second group of variables reflects business experience. International experience is denoted INTL for directors who worked abroad as reported in their résumé or who are foreigners. ${ }^{7}$ CEOEX indicates directors with experience as CEOs. Other executive activities have been excluded because most directors hold or have held management positions during their career. Financial know-how $(F K N)$ is allocated to business or economics graduates (FH and UNI), to bankers, accountants, controllers or chartered accountants, and to graduates of business schools (MBA). INDKN denotes industry know-how, proxied by directors who have conducted research in the area or who are working or have been working in the same industry sector.

\footnotetext{
${ }^{4} \mathrm{FH}$ includes the University of Applied Sciences ("Fachhochschule") or equivalent.

${ }^{5}$ Formerly known as Hochschule St. Gallen (HSG)

${ }^{6}$ These are the universities of Fribourg, Lausanne, Luzern, Neuchâtel, Svizzera italiana in Lugano, and the EPFL in Lausanne (the equivalent of the ETH in Zurich).

${ }^{7}$ Citizens from Liechtenstein (LIE) are not considered as foreigners. The 15 directors from Liechtenstein belong mainly to the Vaduz-based Liechtensteinische Landesbank (7) and VP Bank (5). Dual citizens have been categorized separately according to their life career (e.g., childhood).
} 


\subsection{Control Variables}

The firm-specific know-how of directors is measured by the fraction of executive directors on the board (EXEC) and board tenure (BTEN) which is the average tenure of the board members.

The firm's operational environment is proxied by firm size, its financial situation, the number of business and geographical segments, and the industry affiliation. Firm size is measured by the natural logarithm of annual net sales and denoted $\ln (S A L E S)$. The financial situation is proxied by $N D I V$ and is 1 if the firm did not pay out dividends in 2007 (and 0 otherwise). Financially constrained firms often rely on financial experts.

DIVISIONS is the number of business segments and REGIONS is the number of geographical segments where the corporation has significant business activities differing from other segments.

Moreover, industry fixed effects (INDUSTRY) are crucial in studies on corporate governance since industries differ in the qualification requirements they seek (see Table I). Our respective definition is based on the Industry Classification Benchmark (ICB) which uses 2-digit or super-sector definitions.

Table I: This table presents the distribution of education and business experience in the 6 most important industries in the sample. ICB-Code is the Industry Classification Benchmark code, Obs. is the number of observations. The distribution of education and business experience is measured by the fraction of the board's industrial average. ECO is business and economics, LAW is law, NAT is natural science, and TEC is technical science. INTL is international experience, CEOEX is CEO experience, FKN is financial know-how, and INDKN is industrial know-how.

\begin{tabular}{clccccc}
\hline ICB-Code & Definition & Obs. & ECO & LAW & NAT & TEC \\
\hline 13 & Chemicals & 10 & 0.2845 & 0.1616 & 0.1682 & 0.1892 \\
27 & Industrial Goods \& Services & 49 & 0.2636 & 0.1825 & 0.0760 & 0.2760 \\
37 & Personal \& Household Goods & 12 & 0.1944 & 0.1050 & 0.0536 & 0.2230 \\
45 & Health Care & 22 & 0.2607 & 0.1292 & 0.3792 & 0.1018 \\
83 & Banks & 24 & 0.3166 & 0.2682 & 0.0346 & 0.0639 \\
95 & Technology & 18 & 0.2802 & 0.1724 & 0.0866 & 0.1942 \\
\hline Total sample average & 197 & 0.2858 & 0.1924 & 0.1029 & 0.1642 \\
\hline & & & & & & \\
\hline ICB-Code & Definition & Obs. & INTL & CEOEX & FKN & INDKN \\
\hline 13 & Chemicals & 10 & 0.5909 & 0.4592 & 0.5234 & 0.6625 \\
27 & Industrial Goods \& Services & 49 & 0.5086 & 0.5126 & 0.5899 & 0.5879 \\
37 & Personal \& Household Goods & 12 & 0.4690 & 0.5145 & 0.4724 & 0.6085 \\
45 & Health Care & 22 & 0.6066 & 0.4400 & 0.5107 & 0.7378 \\
83 & Banks & 24 & 0.2359 & 0.4448 & 0.6523 & 0.2886 \\
95 & Technology & 18 & 0.6649 & 0.4571 & 0.5488 & 0.6511 \\
\hline Total sample average & 197 & 0.4751 & 0.4939 & 0.5799 & 0.5562 \\
\hline
\end{tabular}

Table I shows that firms partly compose their boards according to the industry they are in. Health care firms tend to have more natural scientists, whereas in the banking industry there are more economists and lawyers on the board. In contrast, business 
experience does not present such a strong pattern. The low level of average international and industrial experience in the banking industry is most probably attributable to the cantonal banks that primarily operate in Switzerland and whose boards are to some extent politically influenced. However, financial expertise is more evident in the banking industry. Interestingly, the health care industry again shows a high proportion of directors with industrial knowledge.

\subsection{Summary Statistics}

Table II shows that 74.8 percent of all directors have a university degree (UNI), 28.6 percent are graduates of business and economics studies (ECO), and another 19.2 percent studied law (LAW) (see Figure 1). In what concerns the provenance of the degrees, 14.4 percent are graduates of the ETH Zurich (ETH), 9.4 percent of the University of St. Gallen (SG), and 9.2 percent of the University of Zurich (ZH). Besides, 19.7 percent are graduates of foreign universities (FOU).

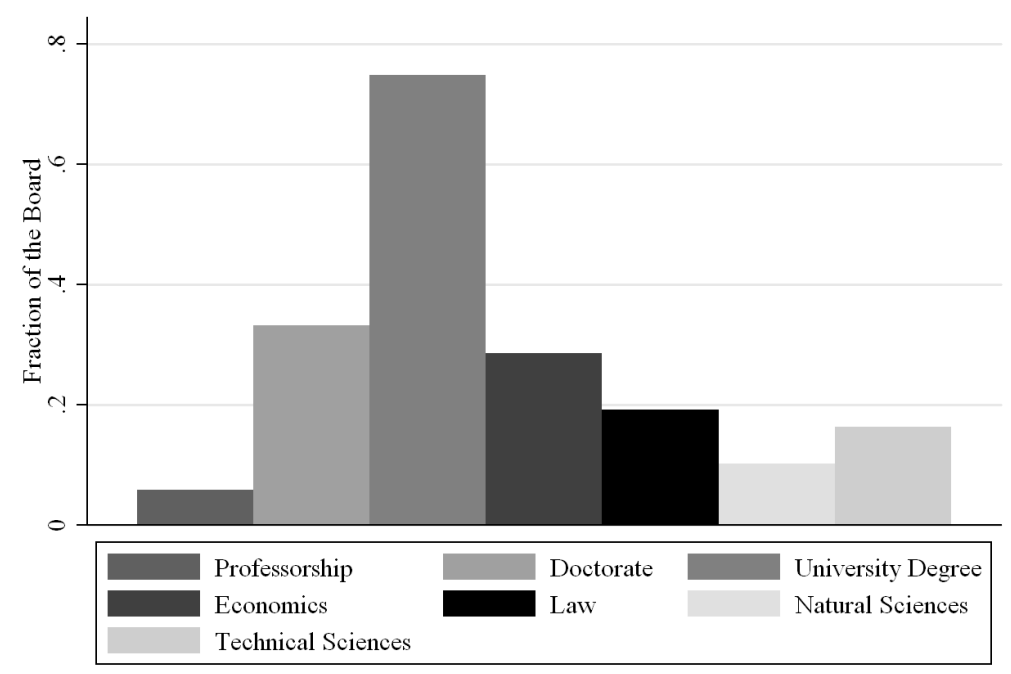

Figure 1: Education of Directors.

Relating to business experience (see Figure 2), on average, 58 percent of the board members have financial expertise (FKN), 56 percent have industrial know-how (IN$\mathrm{DKN}$ ), approximately 50 percent of the directors have experience as CEOs (CEOEX), and 48 percent are internationally experienced (INTL). ${ }^{8}$ Hence, more than half of all board members exhibit financial know-how. In comparison, the sample of Linck et al.

\footnotetext{
${ }^{8}$ Please note that commercial bankers do not play an important role on Swiss boards. This is the reason why this characteristic has been excluded. Directors who can be identified as being commercial bankers on the board of directors on behalf of a credit-lending bank are not identifiable. A possible candidate is Peter Kappeler, chairman of "Berner Kantonalbank" and director of "Jungfraubahnen" in which the bank has a 10-percent ownership stake. In addition, Mr. Kappeler has business relations with "Jungfraubahnen".
} 
(2009) reveals a total of 22 percent for lawyers/consultants (8.91 percent) and financial experts (12.93 percent) on U.S. boards in 2004 .

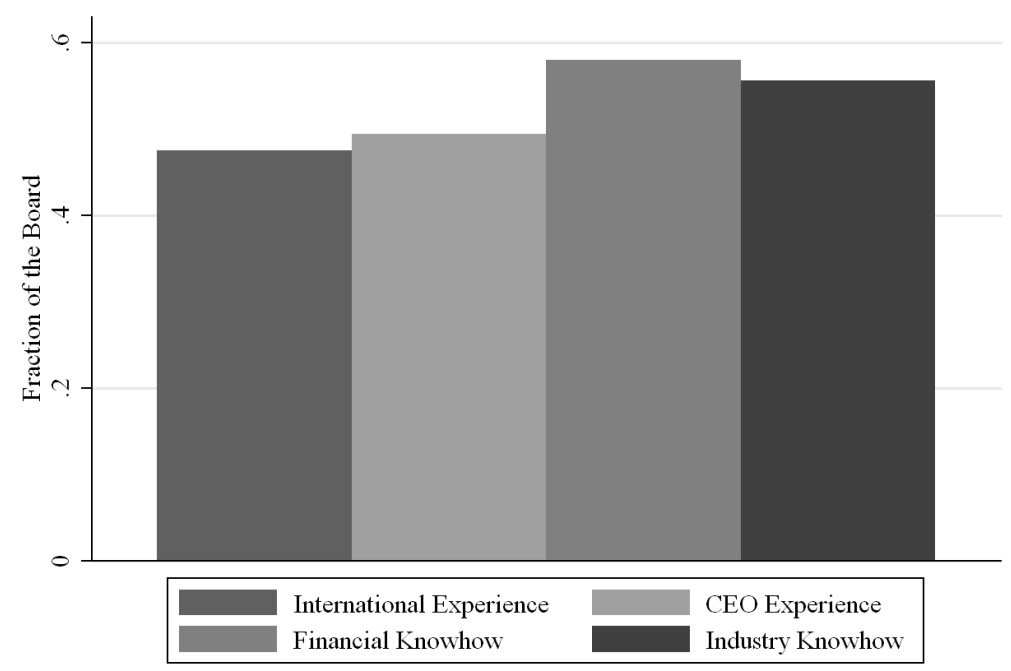

Figure 2: Business Experience of Directors.

\subsection{Boards in Switzerland}

The data give evidence that the firm's industrial affiliation affects the composition of the board (see Table I). Furthermore, we subsequently describe some cases of particularly homogeneous boards. Technology-based corporations have a high amount of graduates from ETH Zurich. ${ }^{9}$ Firms located near the University of St. Gallen have boards composed by more than half of Ex-HSG students. ${ }^{10}$ The same applies for firms in the Basel area or in Lausanne. ${ }^{11}$

Similarly, some boards are composed of graduates of the same field of study. Directors holding law degrees make up half or more of a number of boards including several financial firms. ${ }^{12}$ Another interesting case is the board of "Pargesa", an investment company based in Geneva. Its board comprises four members out of 18 who were educated at the

\footnotetext{
9"Bachem", "Komax", "Lem", "Schaffner", "Starrack Heckert", and "Uster Technologies" (all 60 percent); "Canon", "Schweiter", and "Quadrant" (all 67 percent); and "Comet" and "Newave" 75 and 80 percent, respectively.

10"Hügli" (71 percent), "St. Galler Kantonalbank" (71 percent), "Helvetia" (67 percent), "Bank CA St. Gallen" (63 percent), and "BFW Liegeschaften" (50 percent).

11"Sarasin", "National Suisse", and "Basellandschaftliche Kantonalbank" have 57 percent, 57 percent, and 73 percent graduates from the University of Basel, respectively. The board of "LO Holding" consists of five members who have all studied in Lausanne (University of Lausanne and EPFL).

12"Baloise", "Bellevue Group", "Lindt \& Sprüngli", "Perrot Duval", "SGS", "Swissquote", "Vaudoise Assurances", "Victoria-Jungfrau" (all 50 percent); "Bank Sarasin", "Orell Füssli", "Sopracenerina", "Flughafen Zurich" (all around 60 percent); "Warteck Invest" (67 percent), "Nationale Suisse" (71 percent), and "Allreal" (80 percent).
} 
Table II: Summary statistics of the variables. The sample consists of 197 observations. The table presents mean, median, minimum (Min), and maximum (Max) values as well as standard deviation (S.D.) for each variable. The variables indicate the number of directors with a specific attribution divided by the number of board members. Univ. denotes university and dir. is director.

\begin{tabular}{|c|c|c|c|c|c|c|}
\hline Variable & Definition & Mean & Median & Min & Max & S.D. \\
\hline \multicolumn{7}{|c|}{ Performance Variable } \\
\hline $\mathrm{Q}$ & Tobin's Q & 1.809 & 1.340 & 0.641 & 8.481 & 1.177 \\
\hline \multicolumn{7}{|c|}{ Education: Academic Degree } \\
\hline PR & Fraction of dir. with professorial status & 0.059 & 0.000 & 0.000 & 0.667 & 0.107 \\
\hline DR & Fraction of dir. with doctoral degrees & 0.332 & 0.300 & 0.000 & 1.000 & 0.234 \\
\hline MBA & Fraction of dir. with MBA degrees & 0.142 & 0.111 & 0.000 & 0.600 & 0.154 \\
\hline UNI & Fraction of dir. with university degrees & 0.748 & 0.800 & 0.000 & 1.000 & 0.221 \\
\hline FH & Fraction of dir. with other higher education & 0.060 & 0.000 & 0.000 & 0.667 & 0.122 \\
\hline \multicolumn{7}{|c|}{ Education: Field of Study } \\
\hline ECO & Fraction of business and economics graduates & 0.286 & 0.250 & 0.000 & 1.000 & 0.211 \\
\hline LAW & Fraction of law graduates & 0.192 & 0.182 & 0.000 & 0.714 & 0.156 \\
\hline NAT & Fraction of natural sciences graduates & 0.103 & 0.000 & 0.000 & 0.857 & 0.170 \\
\hline TEC & Fraction of technical sciences graduates & 0.164 & 0.143 & 0.000 & 0.800 & 0.176 \\
\hline \multicolumn{7}{|c|}{ Education: Place of Education } \\
\hline BS & Fraction of Univ. Basel graduates & 0.051 & 0.000 & 0.000 & 0.727 & 0.120 \\
\hline $\mathrm{BE}$ & Fraction of Univ. Berne graduates & 0.029 & 0.000 & 0.000 & 0.400 & 0.071 \\
\hline ETH & Fraction of ETH graduates & 0.144 & 0.100 & 0.000 & 0.800 & 0.187 \\
\hline GE & Fraction of Univ. Geneva graduates & 0.024 & 0.000 & 0.000 & 0.500 & 0.070 \\
\hline SG & Fraction of Univ. St. Gallen graduates & 0.094 & 0.000 & 0.000 & 0.714 & 0.136 \\
\hline $\mathrm{ZH}$ & Fraction of Univ. Zurich graduates & 0.092 & 0.000 & 0.000 & 0.667 & 0.135 \\
\hline OTHU & Fraction of other Swiss Univ. graduates & 0.062 & 0.000 & 0.000 & 0.750 & 0.127 \\
\hline FOU & Fraction of international Univ. graduates & 0.197 & 0.143 & 0.000 & 1.000 & 0.230 \\
\hline \multicolumn{7}{|c|}{ Business Experience } \\
\hline INTL & Fraction of internationally experienced dir. & 0.475 & 0.500 & 0.000 & 1.000 & 0.301 \\
\hline CEOEX & Fraction of dir. with experience as CEOs & 0.494 & 0.500 & 0.000 & 1.000 & 0.217 \\
\hline FKN & Fraction of dir. with financial know-how & 0.580 & 0.600 & 0.000 & 1.000 & 0.237 \\
\hline INDKN & Fraction of dir. with industrial know-how & 0.556 & 0.571 & 0.000 & 1.000 & 0.265 \\
\hline \multicolumn{7}{|c|}{ Control Variables } \\
\hline EXEC & Fraction of insiders & 0.114 & 0.000 & 0.000 & 1.000 & 0.167 \\
\hline BTEN & Average board tenure (in years) & 7.711 & 6.889 & 1.500 & 25.000 & 3.935 \\
\hline NDIV & 1 if no dividends paid in 2007 & 0.223 & - & - & - & - \\
\hline SALES & Net annual sales (in CHF million) & 4,416 & 458 & 0 & 109,100 & 13,673 \\
\hline DIVISIONS & Number of divisions & 2.340 & 2.000 & 1.000 & 10.000 & 1.329 \\
\hline REGIONS & Number of regions & 3.274 & 3.000 & 1.000 & 10.000 & 1.719 \\
\hline
\end{tabular}


Ecole Nationale d'Administration (ENA), an elite civil servant graduate school in France.

In many countries, business is in the hands of a homogeneous upper class like in the Netherlands and Sweden or of families like in Asia (Non and Franses, 2007; Claessens et al., 2000). This is partly also the case in Switzerland. However, over 87 percent of all directors sit only on one board in comparison to 83 percent in the United States and 9 percent sit on two boards in contrast to 13 percent in the United States (RiskMetrics Groups, 2008). Table III Panel A reports that the 1,574 directorships are shared by 1,349 directors. This means that every director has 1.167 directorships on average in a company of the sample (excluding the directorships in non-listed firms). The director categories that accumulated above-average directorships of the seats (i.e., > 1.167) are professors (1.211), directors holding a Ph.D. (1.239), directors holding an MBA (1.203), and university graduates in general (1.179). Law, technical sciences or business and economics graduates occupy an above-average share of the seats, as well $(1.258,1.189$, and 1.181, respectively). Furthermore, all the directors from the universities listed in our survey hold more seats ranging from $1.250(\mathrm{GE})$ to $1.429(\mathrm{ZH})$. Also directors with CEO experience and financial know-how have 1.206 and 1.182 seats on average. In contrast, directors educated at foreign universities and directors with international experience (1.061 and 1.125) show below-average representation.

\section{Empirical Analysis}

The empirical analysis is divided into five parts. First, a univariate ordinary least squares (OLS) analysis is conducted relating one explanatory variable to the response variable. Next, the second analysis uses multivariate models that include several control variables. A third set of analyses examines relationships between education indices and Tobin's Q. The first three sets of models use data from 197 firm observations (224 excluding 27 investment companies). The fourth and fifth sets of analysis investigate the relationships at the level of individual directors and use director fixed effects with a data sample of 1,574 observations.

\subsection{Univariate Ordinary Least Squares (OLS) Analysis}

Table IV, Column I, presents the univariate results of all variables of interest that reveal a significant relationship to Tobin's $Q$. Out of the 17 proxies included to account for education, 7 variables (MBA, ECO, LAW, NAT, ZH, OTHU, and FOU) have a statistically significant relationship to $Q$. From the 4 business experience variables, 2 attributes (INTL and INDKN) are significantly related to $\mathrm{Q}$. However, such regressions have serious omitted variable biases. Hence, in Column II the same relationship is measured, but 
Table III: This table reports the absolute number of director characteristic observations. The table distinguishes between directorships and individual directors. Occ. Rate is the occupancy rate defined as the ratio of the number of directors to the number of seats. 1,574 directorships are held by 1,349 individuals in 224 firms.

\begin{tabular}{|c|c|c|c|}
\hline \multicolumn{4}{|l|}{ Panel A: Directorships and Number of Directors } \\
\hline Number of directorships & 1,574 & & \\
\hline Directors with 5 directorships & 2 & & \\
\hline Directors with 4 directorships & 9 & & \\
\hline Directors with 3 directorships & 32 & & \\
\hline Directors with 2 directorships & 126 & & \\
\hline Directors with 1 directorship & 1,180 & & \\
\hline Number of directors & 1,349 & & \\
\hline \multicolumn{4}{|l|}{ Panel B: Director Characteristics } \\
\hline Total & $\begin{array}{l}\text { Seats } \\
1,574\end{array}$ & $\begin{array}{c}\text { Directors } \\
1,349\end{array}$ & $\begin{array}{c}\text { Occ. Rate } \\
116.68 \%\end{array}$ \\
\hline \multicolumn{4}{|l|}{ Education: Degree } \\
\hline Professor title (Prof.) & 92 & 76 & $121.05 \%$ \\
\hline Doctorate (Dr. / Ph.D.) & 518 & 418 & $123.92 \%$ \\
\hline Master of Business Administration (MBA) & 219 & 182 & $120.33 \%$ \\
\hline University & 1,197 & 1,015 & $117.93 \%$ \\
\hline University of Applied Sciences and equivalent & 72 & 64 & $112.50 \%$ \\
\hline \multicolumn{4}{|l|}{ Education: Field of Study } \\
\hline Economics & 464 & 393 & $118.07 \%$ \\
\hline Law & 327 & 260 & $125.77 \%$ \\
\hline Natural sciences & 150 & 133 & $112.78 \%$ \\
\hline Technical sciences & 233 & 196 & $118.88 \%$ \\
\hline \multicolumn{4}{|l|}{ Education: University } \\
\hline Basel & 85 & 65 & $130.77 \%$ \\
\hline Berne & 49 & 38 & $128.95 \%$ \\
\hline ETH Zurich & 196 & 154 & $127.27 \%$ \\
\hline Geneva & 40 & 32 & $125.00 \%$ \\
\hline St. Gallen & 152 & 119 & $127.73 \%$ \\
\hline Zurich & 150 & 105 & $142.86 \%$ \\
\hline Other Swiss university & 101 & 91 & $110.99 \%$ \\
\hline Foreign university & 333 & 314 & $106.05 \%$ \\
\hline \multicolumn{4}{|l|}{ Business Experience } \\
\hline International experience & 756 & 672 & $112.50 \%$ \\
\hline CEO experience & 767 & 636 & $120.60 \%$ \\
\hline Financial know-how & 950 & 804 & $118.16 \%$ \\
\hline Industrial know-how & 840 & 725 & $115.86 \%$ \\
\hline
\end{tabular}


this time including industry fixed effects. Here, only the fraction of directors educated at one of the other Swiss university (OTHU) is still negatively related to Tobin's $Q$, and only the fraction of directors educated abroad (FOU) is still positively related to it. Furthermore, the table shows that standard errors are stable across the models, indicating that there is no problem of multicollinearity with industry effects.

In general, the reason for these low relationships is not surprising. For instance, in the case of natural scientists (NAT), it is quite obvious that they are unlikely to be equally valuable across all industries and that the relationship loses its significance when industry affiliation is included. In the words of Hermalin and Weisbach (2003), boards are, on average, mostly in equilibrium. The average board cannot be improved with a change in its composition, because it is already adequately structured.

Table IV: This table presents (only significant) univariate regression coefficient estimates of the association of Tobin's Q (the response variable) and an explanatory variable. The sample consists of 197 SPI firm observations in 2008. The coefficients are estimated using OLS estimates with White (1980) robust standard errors. Standard errors are reported in parentheses and significance at the 1 percent, 5 percent, and 10 percent levels is indicated by ***,**, and *, respectively. $R^{2}$ is also reported.

\begin{tabular}{lcccc}
\hline \multirow{2}{*}{$\begin{array}{l}\text { Independent } \\
\text { Variable }\end{array}$} & \multicolumn{3}{c}{ Dependent Variable: Tobin's Q } \\
& Industries excluded & \multicolumn{2}{c}{ Industries included } \\
\cline { 2 - 5 } & $(\mathrm{I})$ & $R^{2}$ & (II) & $R^{2}$ \\
\hline MBA & $1.2774^{* *}$ & 0.0280 & 0.5160 & 0.2996 \\
& $(0.640)$ & & $(0.617)$ & \\
ECO & $-0.7390^{* *}$ & 0.0175 & -0.5192 & 0.3036 \\
& $(0.349)$ & & $(0.345)$ & \\
LAW & $-1.3892^{* * *}$ & 0.0340 & -0.5180 & 0.2996 \\
& $(0.458)$ & & $(0.486)$ & \\
NAT & $2.7003^{* * *}$ & 0.1517 & 1.0870 & 0.3111 \\
& $(0.856)$ & & $(0.998)$ & \\
ZH & $-0.8640^{* *}$ & 0.0099 & -0.3849 & 0.2974 \\
& $(0.428)$ & & $(0.497)$ & \\
OTHU & $-1.3220^{* *}$ & 0.0202 & $-1.2038^{*}$ & 0.3114 \\
& $(0.434)$ & & $(0.471)$ & \\
FOU & $1.3564^{* * *}$ & 0.0705 & $0.7390^{* *}$ & 0.3138 \\
& $(0.394)$ & & $(0.366)$ & \\
INTL & $0.9341^{* * *}$ & 0.0573 & 0.4440 & 0.3061 \\
& $(0.265)$ & & $(0.274)$ & \\
INDKN & $1.2170^{* * *}$ & 0.0752 & 0.3755 & 0.3011 \\
& $(0.311)$ & & $(0.282)$ & \\
\hline
\end{tabular}

\subsection{Multivariate Analysis}

\subsubsection{Correlation Matrix}

Table V displays the Pearson's correlation matrix of relevant variables. The correlations document how boards trade-off different capabilities. Note that the variables are board averages. This explains correlations between different education variables. Firstly, no variables depict a high correlation of over 0.7 that - as a rule of thumb - usually would 
lead to a multicollinearity problem when the two variables are included in the same model. The variance inflation factors (VIF) confirm this finding (except for the industry dummies which, however, are not interpreted individually). However, financial knowhow (FKN) is correlated (0.6) with directors who have studied economics (ECO), as can be expected because of the definition of financial know-how. Law graduates (LAW) are negatively related to industrial knowledge (INDKN), underlining their support function on a board, while technical (TEC) and natural scientists (NAT) are positively related to industrial know-how. Internationally experienced directors (INTL) are positively correlated with the number of geographical segments (REGIONS).

\subsubsection{Analysis on Education}

The first set of multivariate models regresses Tobin's $Q$ on variables of education. Columns I and II in Table VI employ the field of study, Columns III and IV the academic degree, and Columns V and VI use the place of education as independent variables. Each of these sets compares the educational variables alone first, and in a second step in addition to the control variables. The results indicate that most of the significant relations disappear if control variables are included. The educational variables that have the greatest explanatory power are related to the field of study $\left(R^{2}=17.08\right.$ percent $)$. The only significant relationship that persists is the negative one between education at another Swiss university (OTHU) and Tobin's Q. This relationship disappears if a dummy variable, as control variable for the French-speaking area, is included where most of these minor universities are based (not presented). However, as the variables OTHU and FRA are nearly interchangeable, but not collinearly related, we believe that the education of the directors is a more important determinant of Tobin's $Q$ than the location of the firm.

The possible reason for these weak relations, once more, is that boards are composed up to their needs. For example, the positive relationship between natural scientists (NAT) and Tobin's $Q$ vanishes if the regression model is run on a subsample of health care firms or if only the affiliation to the health care industry is held constant (not presented). Another example is the positive relation between the fraction of graduates of universities abroad (FOU) and Tobin's Q, as well as the number of geographical segments (REGIONS) (t-statistics: $3.5135(* * *))$. REGIONS, in turn, is positively related to Tobin's Q (t-statistics: $1.9156(*))$, and when controlled for this circumstance, the variable FOU loses its significance. When specifying definitions tightly (e.g., law graduates from the University of Zurich) no significance was evident at all (not presented).

\subsubsection{Analysis on Business Experience}

The second set of variables relates to business experience. The 4 business experience variables already explain 12.23 percent of the variation in Tobin's $\mathrm{Q}\left(R^{2}\right)$ (Table VII, 


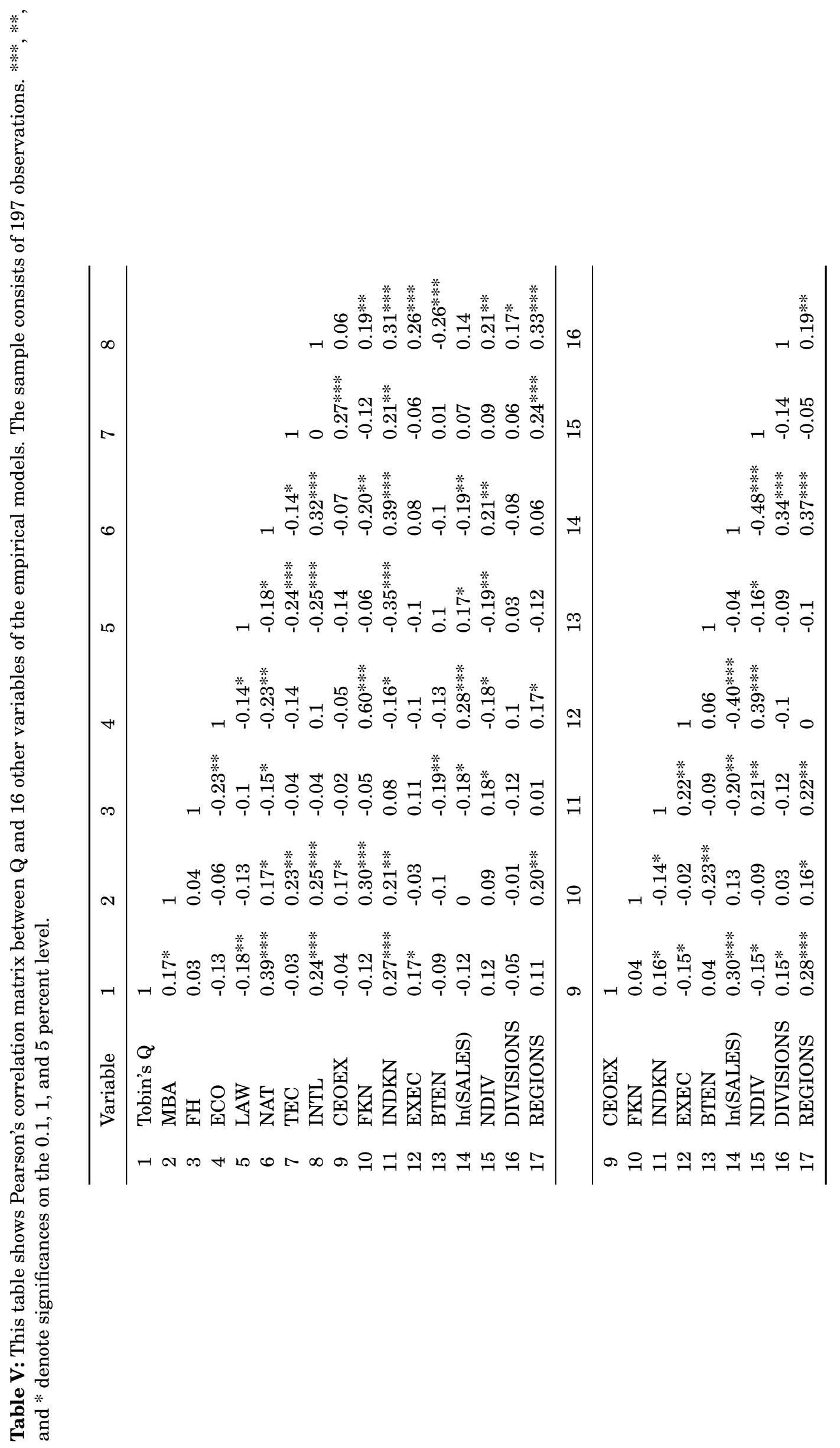




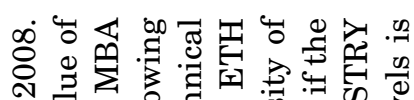
等

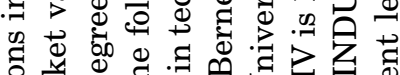
b

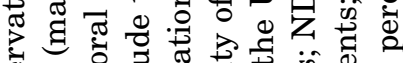

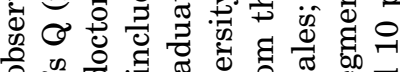

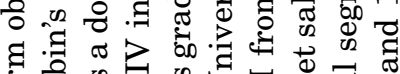

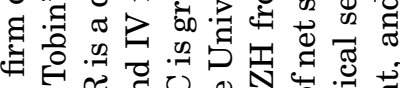

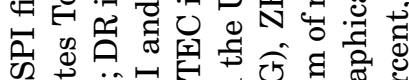

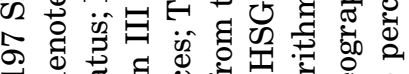
0

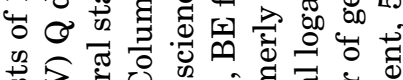
蓄合

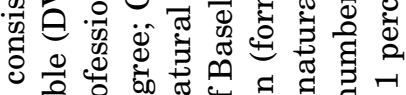

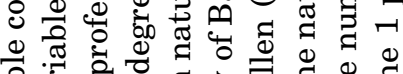
음 흔

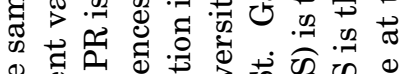

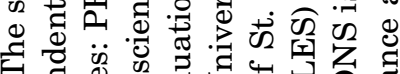

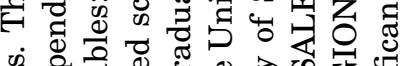
为

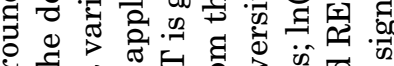

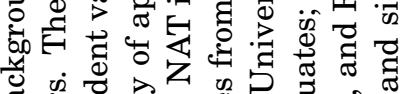
总

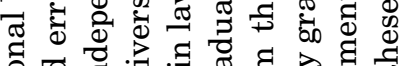

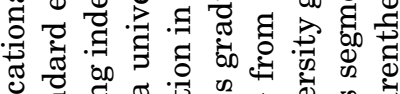

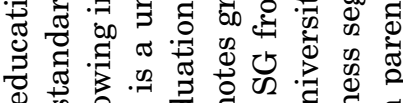

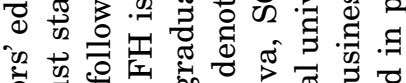

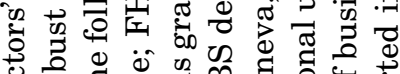

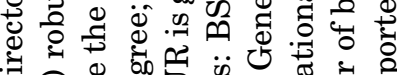

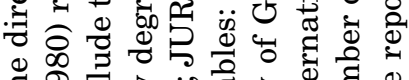

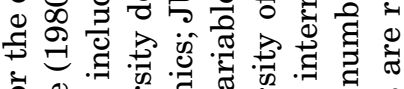
b

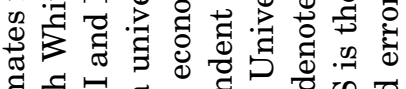

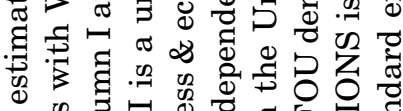

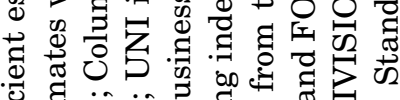

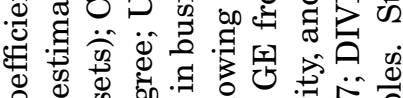
o

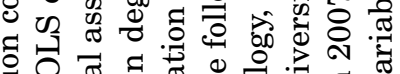

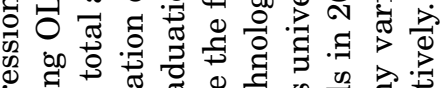

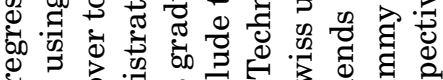

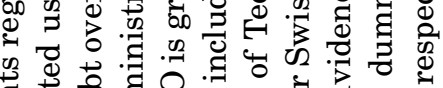

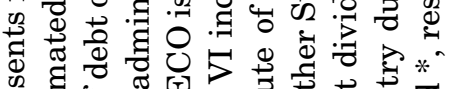

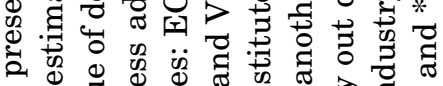
a d 这郭 일

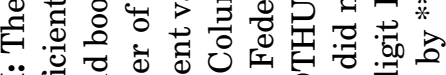

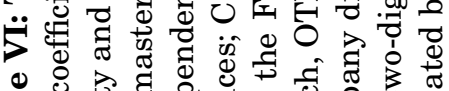

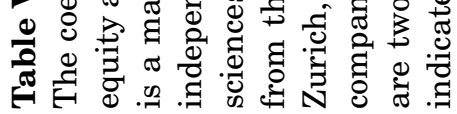

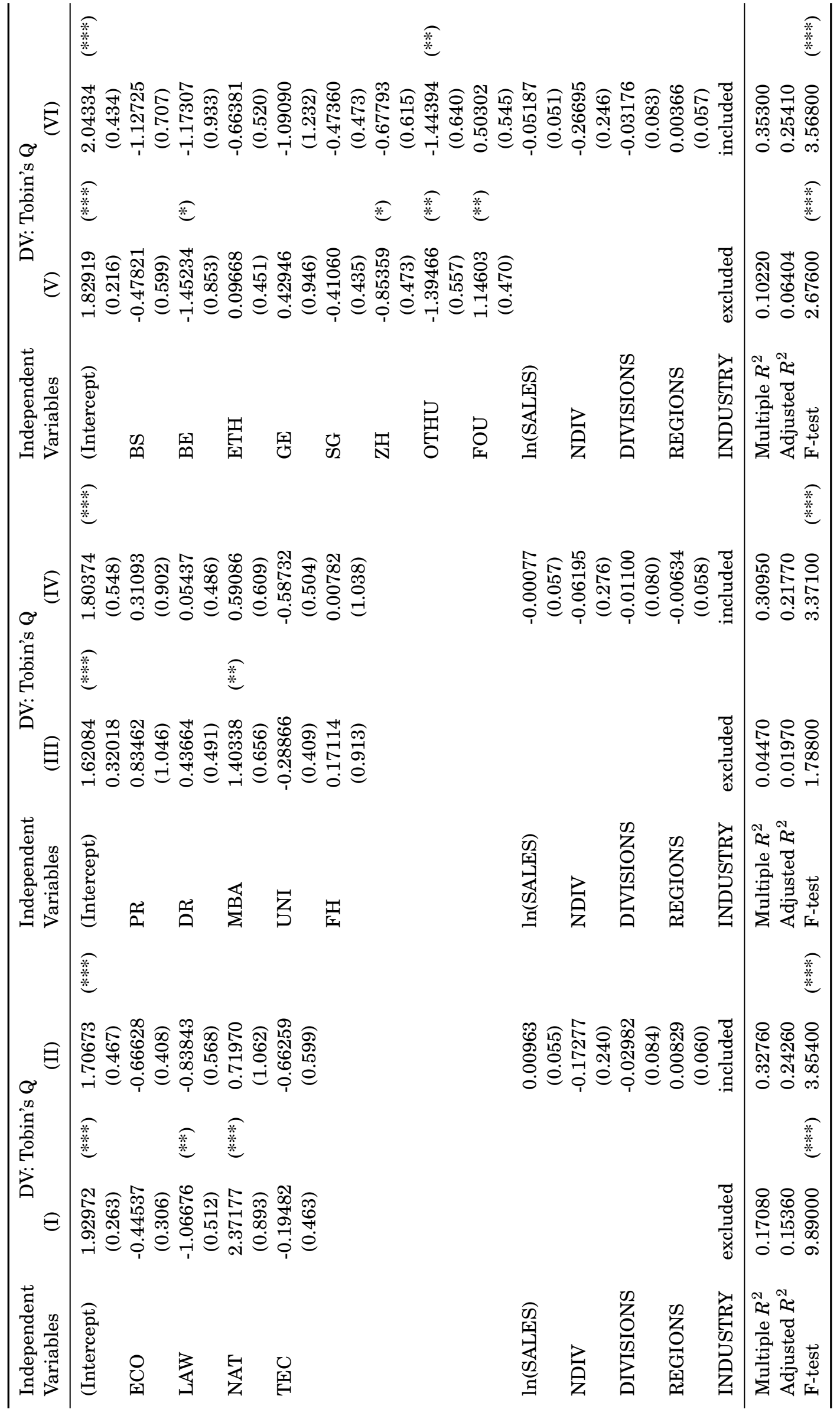


Column I). International experience (INTL) and industrial knowledge (INDKN) are positively related to $\mathrm{Q}$ while financial know-how (FKN) shows a negative relationship. These relationships remain unchanged if board experience (EXEC and BTEN) and factors in the operating environment ( $\ln ($ SALES), NDIV, DIVISIONS, and REGIONS) are included (Columns II and III). However, industry fixed effects make these relationships disappear again (Column IV).

In the last Column (V), we include interaction terms with DIVISIONS and REGIONS interplaying with business experience. ${ }^{13}$ International experience is expected to be valuable if the firm has sales around the world, and CEO experience can add value if the firm is developing in various regions. So, the interaction terms include REGIONS with INTL and CEOEX. In addition, the variable DIVISIONS interacts with financial know-how (FKN) and industrial know-how (INDKN). Financial know-how is important if the firm has a corporate center with a treasury. This is usually the case if a company has more than one division. In contrast, industrial know-how is more valuable if the firm operates in only few business segments. The results indicate that industrial knowledge is indeed negatively related to $\mathrm{Q}$ if it is interacted with the number of divisions.

\subsection{Analysis of Indices}

Debates criticizing boards for being overly homogeneous in appealing to a strict sense of diversity ignore the fact that many directors can be linked together through alumni associations or other groups and may therefore also lack independence (see Schletti, 2006). This perspective is especially critical in a small country such as Switzerland where many managers and directors are graduates of the same university. On the one hand, it is very important that the linkages among board members are not too strong in order to prevent collusion and to promote opinion-building. On the other hand, mutual respect may be beneficial in tense situations.

In order to investigate the possible influence of educational diversity, we employ two series of concentration indices: the Herfindahl-Hirschman and the Shannon indices (see Appendix Section .1). Both indices measure the concentration in the "field of study" (HHIEDU and SHIEDU) and "place of education" (HHIUNI and SHIUNI). Table VIII reveals that no index relating to educational diversity on the board is close to being significantly related to firm performance. Hence, personal affiliations between board members owing to a joint education is not relevant to valuation.

\footnotetext{
${ }^{13}$ In order to circumvent multicollinearity problems with the interaction terms, the variables in the interaction terms have been centered. In other words, the sample average values of the variables have been subtracted from the values of the variables for each observation.
} 


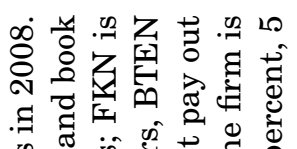

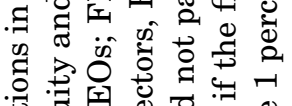

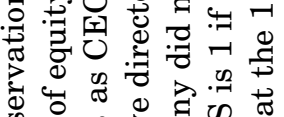

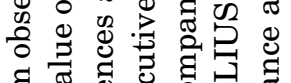

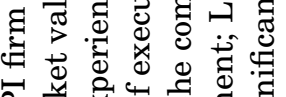

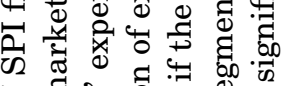

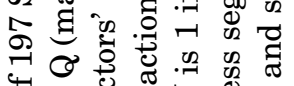

on 0 on

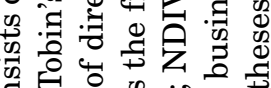

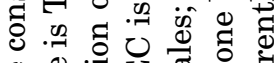

응

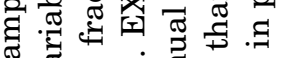

施

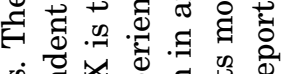

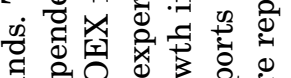

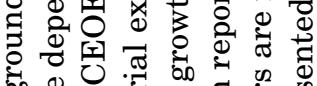

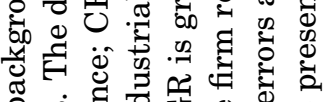

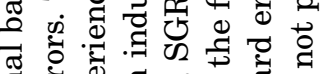

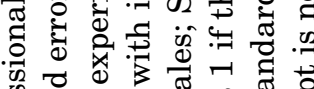

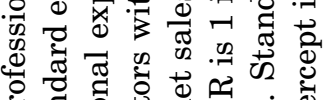

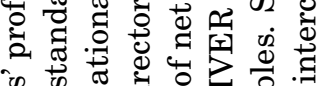

कि

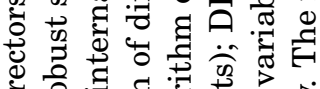

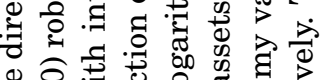

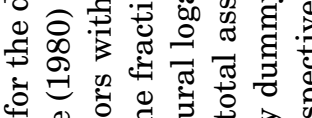

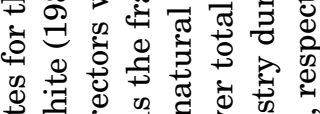

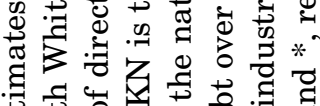

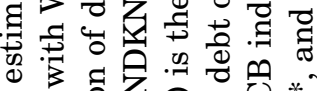

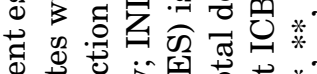

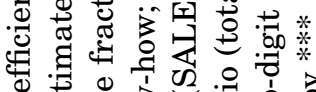

8

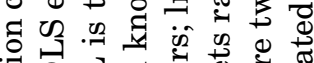

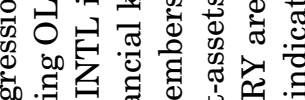

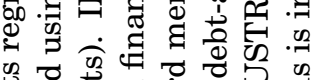

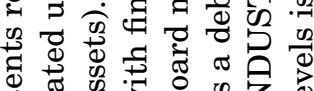

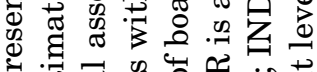

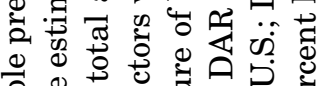

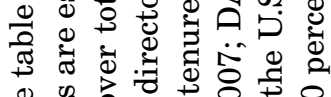

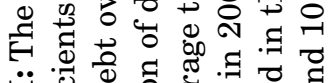

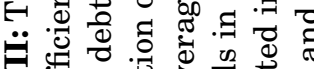

象

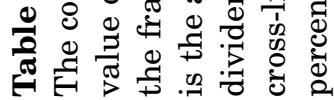

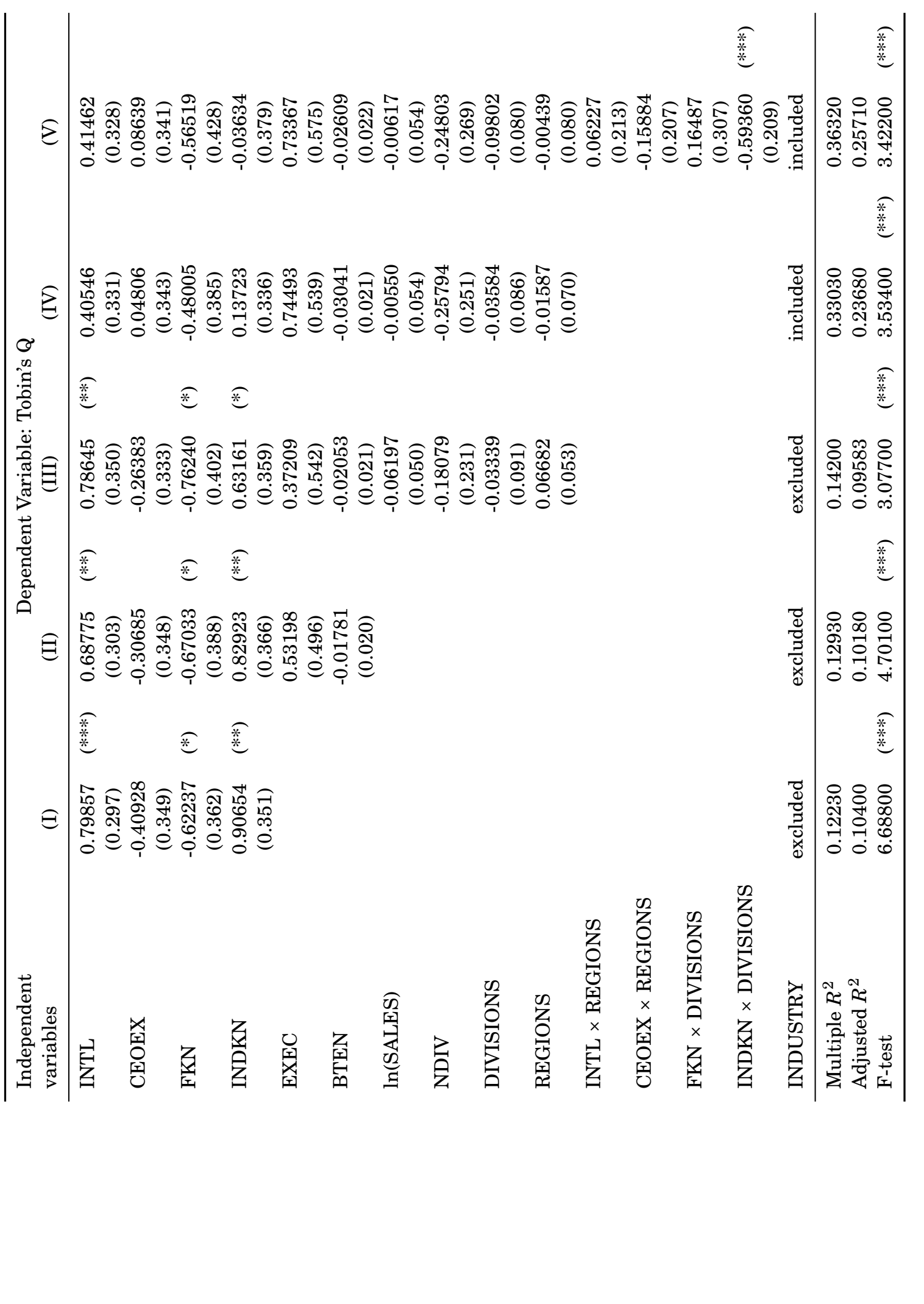


Table VIII: The table presents regression coefficient estimates of the association of Q with different concentration indices. The sample consists of 197 SPI firm observations in 2008. The coefficients are estimated using OLS estimates with White (1980) robust standard errors. The dependent variable is Tobin's $\mathrm{Q}$ (market value of equity and book value of debt over total assets). HHIEDU is the Herfindahl index of the field of study; SHIEDU is the Shannon index of the field of study. HHIUNI is the Herfindahl index of the attended university; SHIUNI is the Shannon index of the attended university. The models include the following control variables: $\ln$ (SALES) is the natural logarithm of net sales; NDIV is 1 if the company did not pay out dividends in 2007; DIVISIONS is the number of business segments and REGIONS is the number of geographical segments; INDUSTRY are two-digit ICB industry dummy variables. In addition, the intercept is dropped to save space. Standard errors are reported in parentheses and significance at the 1 percent, 5 percent, and 10 percent levels is indicated by ***, **, and *, respectively.

\begin{tabular}{|c|c|c|c|c|c|c|c|c|}
\hline \multirow{2}{*}{$\begin{array}{l}\text { Independent } \\
\text { Variables }\end{array}$} & \multicolumn{7}{|c|}{ Dependent Variable: Tobin's Q } & \\
\hline & (I) & & (II) & & (III) & & (IV) & \\
\hline HHIEDU & $\begin{array}{c}-0.07066 \\
(0.651)\end{array}$ & & & & & & & \\
\hline SHIEDU & & & $\begin{array}{c}-0.18510 \\
(0.307)\end{array}$ & & & & & \\
\hline HHIUNI & & & & & $\begin{array}{c}-0.10025 \\
(0.484)\end{array}$ & & & \\
\hline SHIUNI & & & & & & & $\begin{array}{c}-0.13846 \\
(0.194)\end{array}$ & \\
\hline Control Variables & included & & included & & included & & included & \\
\hline Multiple $R^{2}$ & 0.29700 & & 0.29880 & & 0.29710 & & 0.29920 & \\
\hline Adjusted $R^{2}$ & 0.22150 & & 0.22360 & & 0.22160 & & 0.22390 & \\
\hline F-test & 3.93500 & $(* * *)$ & 3.97000 & $(* * *)$ & 3.93700 & $(* * *)$ & 3.97700 & $(* * *)$ \\
\hline
\end{tabular}

\subsection{Analysis at the Level of Individual Directors}

All the precedent models employed aggregated values at the board level. In the next step, therefore, we use data at the level of individual directors which contains 1,574 observations. This sample allows us to examine interactions between the educational and professional backgrounds of directors and two broad demographic classifications of directors, namely gender and nationality. The fraction of females on the board is denoted GEN and the fraction of foreigners is FOR. Table IX, Column I, displays results of estimates using this data sample. Graduates of natural science (NAT) as well as directors with international (INTL) and industrial experience (INDKN) are positively related to Tobin's Q. CEO experience (CEOEX) and firm performance are negatively correlated. These main results remain stable after including interactions. However, when taking industryeffects into account, all but the positive relationship between international experience and firm performance vanish. Conversely, foreign directors with CEO experience negatively affect the valuation. Such directors may be appointed on boards solely for their fame or may be too busy to mind their duties. The opposite is true for CEO experienced females and women graduates of business and economics. Finally, females with financial know-how are negatively correlated with Tobin's Q. Quite obviously, having international experience seems to be more important than simply being a foreigner. 
Table IX: The table presents regression coefficient estimates of the association of $\mathrm{Q}$ and individual director characteristics. The sample consists of 1,574 director observations in 2008 . The coefficients are estimated using OLS estimates with White (1980) robust standard errors. The dependent variable is Tobin's Q (market value of equity and book value of debt over total assets). The independent variables are dummy variables for characteristics at the level of individual directors and include the following attributes: FOR are foreigners; GEN are women; ECO are business and economics graduates; LAW are law graduates; NAT are natural sciences graduates; TEC are technical sciences graduates; INTL is international experience; CEOEX is experience as CEO; FKN is financial know-how; INDKN is industrial experience. INDUSTRY are two-digit ICB industry dummy variables. Standard errors are reported in parentheses and significance at the 1 percent, 5 percent, and 10 percent levels is indicated by ***,**, and *, respectively.

\begin{tabular}{|c|c|c|c|c|c|c|}
\hline \multirow{3}{*}{$\begin{array}{l}\text { Independent } \\
\text { variables } \\
\text { (Intercept) }\end{array}$} & \multicolumn{6}{|c|}{ Dependent Variable: Tobin's Q } \\
\hline & \multicolumn{2}{|c|}{ (I) } & \multicolumn{2}{|c|}{ (II) } & \multicolumn{2}{|c|}{ (III) } \\
\hline & 1.51152 & $(* * *)$ & 1.43865 & $(* * *)$ & 1.06522 & $(* * *)$ \\
\hline & $(0.087)$ & & $(0.097)$ & & $(0.172)$ & \\
\hline \multirow[t]{2}{*}{ FOR } & 0.27745 & $(* *)$ & 0.21407 & & 0.21269 & \\
\hline & $(0.139)$ & & $(0.495)$ & & $(0.334)$ & \\
\hline \multirow[t]{2}{*}{ GEN } & -0.09087 & & 0.09743 & & 0.23509 & \\
\hline & $(0.147)$ & & $(0.252)$ & & $(0.223)$ & \\
\hline \multirow[t]{2}{*}{ ECO } & 0.04086 & & -0.05213 & & -0.07966 & \\
\hline & $(0.118)$ & & $(0.090)$ & & $(0.087)$ & \\
\hline \multirow[t]{2}{*}{ LAW } & -0.03947 & & 0.06341 & & -0.02769 & \\
\hline & $(0.097)$ & & $(0.107)$ & & $(0.104)$ & \\
\hline \multirow[t]{2}{*}{ NAT } & 0.55685 & $(* * *)$ & 0.85674 & $(* * *)$ & 0.26638 & \\
\hline & $(0.168)$ & & $(0.216)$ & & $(0.185)$ & \\
\hline \multirow[t]{2}{*}{ TEC } & -0.07573 & & 0.02825 & & -0.06603 & \\
\hline & $(0.090)$ & & $(0.096)$ & & $(0.087)$ & \\
\hline \multirow[t]{2}{*}{ INTL } & 0.32068 & $(* * *)$ & 0.34805 & $(* * *)$ & 0.19650 & $(* *)$ \\
\hline & $(0.088)$ & & $(0.091)$ & & $(0.086)$ & \\
\hline \multirow[t]{2}{*}{ CEOEX } & -0.23062 & $(* * *)$ & -0.13698 & $(*)$ & -0.04365 & \\
\hline & $(0.088)$ & & $(0.077)$ & & $(0.072)$ & \\
\hline \multirow[t]{2}{*}{ FKN } & -0.06537 & & -0.05450 & & -0.04419 & \\
\hline & $(0.085)$ & & $(0.089)$ & & $(0.084)$ & \\
\hline \multirow[t]{2}{*}{ INDKN } & 0.33967 & $(* * *)$ & 0.28655 & $(* * *)$ & 0.06572 & \\
\hline & $(0.083)$ & & $(0.071)$ & & $(0.066)$ & \\
\hline \multirow[t]{2}{*}{$\mathrm{FOR} \times \mathrm{ECO}$} & & & 0.20185 & & 0.25372 & \\
\hline & & & $(0.344)$ & & $(0.742)$ & \\
\hline \multirow[t]{2}{*}{$\mathrm{FOR} \times \mathrm{LAW}$} & & & -0.43060 & & -0.23820 & \\
\hline & & & $(0.324)$ & & $(0.287)$ & \\
\hline \multirow[t]{2}{*}{$\mathrm{FOR} \times \mathrm{NAT}$} & & & -0.81838 & $(* *)$ & -0.46335 & \\
\hline & & & $(0.358)$ & & $(0.313)$ & \\
\hline \multirow[t]{2}{*}{$\mathrm{FOR} \times \mathrm{TEC}$} & & & -0.36182 & & -0.21896 & \\
\hline & & & $-(1.541)$ & & $(0.208)$ & \\
\hline \multirow[t]{2}{*}{ FOR $\times$ INTL } & & & 0.27433 & & -0.09934 & \\
\hline & & & $(0.483)$ & & $(0.300)$ & \\
\hline FOR $\times$ CEOEX & & & $\begin{array}{c}-0.44157 \\
(0.262)\end{array}$ & $(*)$ & $\begin{array}{c}-0.43482 \\
(0.248)\end{array}$ & $(*)$ \\
\hline
\end{tabular}


Individual-level - continued

\begin{tabular}{|c|c|c|c|c|c|c|}
\hline \multirow{2}{*}{$\begin{array}{l}\text { Independent } \\
\text { variables }\end{array}$} & \multicolumn{6}{|c|}{ Dependent Variable: Tobin's Q } \\
\hline & (I) & & \multicolumn{2}{|c|}{ (II) } & \multicolumn{2}{|c|}{ (III) } \\
\hline \multirow[t]{2}{*}{ FOR $\times$ FKN } & & & 0.06550 & & 0.19385 & \\
\hline & & & $(0.258)$ & & $(0.245)$ & \\
\hline \multirow[t]{2}{*}{ FOR $\times$ INDKN } & & & 0.15480 & & 0.33779 & \\
\hline & & & $(0.253)$ & & $(0.243)$ & \\
\hline \multirow[t]{2}{*}{ GEN $\times$ ECO } & & & 0.90415 & $(* *)$ & 0.70591 & $(*)$ \\
\hline & & & $(0.450)$ & & $(0.416)$ & \\
\hline \multirow[t]{2}{*}{ GEN $\times$ LAW } & & & -0.31832 & & -0.05630 & \\
\hline & & & $(0.252)$ & & $(0.234)$ & \\
\hline \multirow[t]{2}{*}{ GEN $\times$ NAT } & & & 1.64398 & & 1.32077 & \\
\hline & & & (1.111) & & $(0.973)$ & \\
\hline \multirow[t]{2}{*}{ GEN $\times$ TEC } & & & -0.37824 & & 0.21617 & \\
\hline & & & $(0.344)$ & & $(0.314)$ & \\
\hline \multirow[t]{2}{*}{ GEN $\times$ INTL } & & & -0.64753 & $(*)$ & -0.44248 & \\
\hline & & & $(0.347)$ & & $(0.326)$ & \\
\hline \multirow[t]{2}{*}{ GEN $\times$ CEOEX } & & & 1.03597 & $(* * *)$ & 0.65479 & $(*)$ \\
\hline & & & $(0.364)$ & & $(0.348)$ & \\
\hline \multirow[t]{2}{*}{ GEN $\times$ FKN } & & & -0.96827 & $(* *)$ & -0.97100 & $(* *)$ \\
\hline & & & $(0.440)$ & & $(0.402)$ & \\
\hline \multirow[t]{2}{*}{ GEN $\times$ INDKN } & & & -0.23626 & & -0.32270 & \\
\hline & & & $(0.360)$ & & $(0.352)$ & \\
\hline INDUSTRY & excluded & & excluded & & included & \\
\hline Multiple $R^{2}$ & 0.06311 & & 0.08311 & & 0.18630 & \\
\hline Adjusted $R^{2}$ & 0.05712 & & 0.06770 & & 0.16340 & \\
\hline F-test & 10.53000 & $(* * *)$ & 5.39300 & $(* * *)$ & 8.14400 & $(* * *)$ \\
\hline
\end{tabular}

\subsection{Fixed Effects Analysis}

The preceding regressions used data at the level of individual directors which contained 1,574 observations. Director characteristics have thus been tackled more precisely, but the omitted-variable bias continues to present a problem. Directors can still differ significantly in personal characteristics (e.g., talent) other than the variables defined. Hence, we employ director fixed effects, using the fact that some directors appear more than once in the sample (see Adams and Ferreira, 2008).

1,574 seats are shared by 1,349 directors (see Table III). This fact allows us to test for fixed effects. Specifically, we attribute a unique dummy variable to each director who serves on more than one board. This methodology captures unobservable director-level heterogeneity for those directors and facilitates an investigation of whether unexplained or unobserved features drive firm valuation. One property of fixed effects is that they ex- 
plain only invariant omitted variables. Thus, director characteristics that do not change between boards such as education or financial knowledge are fixed. ${ }^{14}$ In contrast, other features such as independence with regard to the management of the corporation or industry knowledge are not fixed and do change from one board to another. For this reason, our models consider industry know-how of the directors (INDKN), executive directors (EXEC), former directors (FEXEC), and directors with business relationships (BREL). Since we use cross-sectional (and not panel) data, the fact that directors may gain in experience or education over a long time horizon does not present a problem.

Table X: The table presents regression coefficient estimates of the association of $Q$ and individual director characteristics. The sample consists of 1,574 director observations in 2008 . The coefficients are estimated using OLS estimates with White (1980) robust standard errors. Column III shows coefficient estimates including director fixed effects. The dependent variable Q denotes Tobin's Q (market value of equity and book value of debt over total assets); The independent variables are dummy variables for characteristics at the level of individual directors and include the following attributes: INDKN is industrial know-how; EXEC are insiders (executive directors); FEXEC are former insiders; BREL are directors with business relations to the firm; INDUSTRY are two-digit ICB industry dummy variables. Director Fixed Effects are dummy variables for every director who holds more than one seat in the sample. The table shows estimates, standard errors are reported in parentheses and significance at the 1 percent, 5 percent, and 10 percent levels is indicated by ***,**, and *, respectively.

\begin{tabular}{|c|c|c|c|c|c|c|}
\hline \multirow{2}{*}{$\begin{array}{l}\text { Independent } \\
\text { Variables }\end{array}$} & \multicolumn{6}{|c|}{ Dependent Variable: Tobin's Q } \\
\hline & (I) & & (II) & & (III) & \\
\hline (Intercept) & $\begin{array}{c}1.52202 \\
(0.040)\end{array}$ & $(* * *)$ & $\begin{array}{c}1.12125 \\
(0.107)\end{array}$ & $(* * *)$ & $\begin{array}{c}1.16162 \\
(0.135)\end{array}$ & $(* * *)$ \\
\hline INDKN & $\begin{array}{l}0.38324 \\
(0.076)\end{array}$ & $(* * *)$ & $\begin{array}{c}0.10992 \\
(0.069)\end{array}$ & & $\begin{array}{c}0.13153 \\
(0.072)\end{array}$ & $(*)$ \\
\hline EXEC & $\begin{array}{l}0.65834 \\
(0.226)\end{array}$ & $(* * *)$ & $\begin{array}{c}0.55364 \\
(0.217)\end{array}$ & $(* *)$ & $\begin{array}{c}0.57608 \\
(0.228)\end{array}$ & $(* *)$ \\
\hline FEXEC & $\begin{array}{c}-0.11003 \\
(0.126)\end{array}$ & & $\begin{array}{c}-0.00712 \\
(0.109)\end{array}$ & & $\begin{array}{c}-0.02175 \\
(0.120)\end{array}$ & \\
\hline BREL & $\begin{array}{l}0.27376 \\
(0.157)\end{array}$ & $(*)$ & $\begin{array}{c}0.13780 \\
(0.145)\end{array}$ & & $\begin{array}{c}0.17896 \\
(0.154)\end{array}$ & \\
\hline $\begin{array}{l}\text { INDUSTRY } \\
\text { Director Fixed Effects }\end{array}$ & $\begin{array}{l}\text { excluded } \\
\text { excluded }\end{array}$ & & $\begin{array}{l}\text { included } \\
\text { excluded }\end{array}$ & & $\begin{array}{l}\text { included } \\
\text { included }\end{array}$ & \\
\hline Multiple $R^{2}$ & 0.03677 & & 0.16970 & & 0.22030 & \\
\hline Adjusted $R^{2}$ & 0.03431 & & 0.15850 & & 0.11320 & \\
\hline F-test & 14.97000 & $(* * *)$ & 15.10000 & $(* * *)$ & 2.05700 & $(* * *)$ \\
\hline
\end{tabular}

Table X, Column I, confirms the results from Table IX (Columns I and II) that industrial knowledge (INDKN) is significantly positively related to firm performance. The same relationship appears for executive directors (EXEC) and directors with business

\footnotetext{
${ }^{14}$ The same is true for firm fixed effects which are often used in studies with panel data. Such firm effects are especially powerful if firm characteristics are time-invariant (or stationary) (e.g., industry affiliation).

In contrast, firm characteristics that change such as sales growth are omitted. Bertrand and Schoar (2003) track managers over time and across companies. Hence, in contrast to directors, managers usually only serve for one firm at one and the same time. The empirical evidence shows that firm policies and performance highly depend on managerial fixed effects. Fixed effects account for unobserved heterogeneity among top managers.
} 
relations (BREL). The inclusion of industry effects in Column II leaves only insiders (EXEC) as a significant factor.

Finally, in Column III, the director fixed effects are included. The higher intercept in Column III compared to Column II suggests that the average valuation of multiple directorships is lower than for directors holding only one seat. Furthermore, the integration of such fixed effects increases $R^{2}$ from 16.97 percent to 22.03 percent. In other words, unobserved characteristics of directors appearing more than once in the sample explain only 5 percent of Tobin's $\mathrm{Q}$ and adding variables to a model always increases $R^{2}$. In fact, adjusted $R^{2}$ actually decreases by about 5 percent. Nevertheless, the Waldtest, a heteroskedasticity-robust F-test, provides evidence that these effects significantly improve the model at a 1 percent level of significance.

\section{Conclusions}

Directors have various characteristics that are difficult to proxy. Most studies relating the board to firm performance use simple classifications (e.g., board independence or demography). This study uses a host of variables describing the educational and professional experience of directors.

First of all, the study indicates that firms compose their boards (partly) according to their needs. Natural scientists are common in health care firms, while there is an above average prevalence of economists in banks. The results show that while in univariate analysis there are significant relationships between these variables and Tobin's Q (e.g, a negative relation between lawyers and $Q$ ), these associations almost all vanish if control variables are included (especially industry effects). A persisting and significantly negative relation exists between education at Swiss universities other than those explicitly defined in our study and Tobin's Q. In addition, industrial know-how is significantly negatively related to Tobin's $Q$ interacting with the number of divisions: industrial knowhow is not valuable if the number of business segments is high.

This suggests that, in general, boards are in equilibrium. There is no specific board composition (e.g., a high fraction of economists) that, on average, can enhance firm value. In contrast, lasting relationships, i.e., significant relationships that remain after the inclusion of control variables, suggest that some boards are out of equilibrium. In other words, Tobin's Q could be improved on average if boards were to employ a specific percentage of, say, economists. This is not true in most cases.

Secondly, models that use data at the level of individual directors show that international experience impacts firm valuation while the simple fact of being a foreigner does not - or even lowers firm value in case of foreigners with CEO experience. In addition, females are positively related to Tobin's $Q$ if they are economists and have CEO experience, but there is a negative relationship between financially literate women and firm 
performance.

Thirdly, directors have other unobservable features (e.g., talent) that are usually absorbed in the error term. This heterogeneity may explain missing links between directors and firm performance. If good proxies are unavailable, it is possible to use fixed effects in the case of panel data or, as in our case, cross-sectional data that indicates the presence of directors on more than one board. The results show that director fixed effects improve the explanatory power of the model significantly, but by only around 5 percent (adding variables always increases $R^{2}$ ). In other words, all characteristics that are not observed, such as talent, do only slightly improve the model. 


\section{References}

Adams, R. B. and D. Ferreira, "Do Directors Perform for Pay?," Journal of Accounting and Economics, 2008, 46 (1), 154-171.

_ , B. E. Hermalin, and M. S. Weisbach, "The Role of Boards of Directors in Corporate Governance: A Conceptual Framework and Survey," Journal of Economic Literature, 2010, 48 (1), 58-107.

Baysinger, B. D. and H. N. Butler, "Corporate Governance and the Board of Directors: Performance Effects of Changes in Board Composition," Journal of Law, Economics, and Organization, 1985, 1 (1), 101-124.

Bertrand, M. and A. Schoar, "Managing with Style: The Effect of Managers on Firm Policies," Quarterly Journal of Economics, 2003, 118 (4), 1169-1208.

Byrd, D. T. and M. S. Mizruchi, "Bankers on the Board and the Debt Ratio of Firms," Journal of Corporate Finance, 2005, 11 (1-2), 129-173.

Claessens, S., S. Djankov, and L. H. P. Lang, "The Separation of Ownership and Control in East Asian Corporations," Journal of Financial Economics, 2000, 58 (1-2), 81-112.

DeFond, M. L., R. N. Hann, and X. Hu, "Does the Market Value Financial Expertise on Audit Committees of Boards of Directors?," Journal of Accounting Research, 2005, 43 (2), 153-193.

Dittmann, I., E. G. Maug, and C. Schneider, "Bankers on the Boards of German Firms: What They Do, What They Are Worth, and Why They Are (Still) There," Review of Finance, 2010, 14 (1), 35-71.

Economiesuisse, "Swiss Code of Best Practice for Corporate Governance," Swiss Business Federation, 2008.

Fama, E. F. and M. C. Jensen, "Separation of Ownership and Control," The Journal of Law and Economics, 1983, 26 (2), 301-325.

Güner, A. B., U. Malmendier, and G. Tate, "Financial Expertise of Directors," Journal of Financial Economics, 2008, 88 (2), 323-354.

Hermalin, B. E. and M. S. Weisbach, "Boards of Directors as an Endogenously Determined Institution: A Survey of the Economic Literature," Economic Policy Review, 2003, 9 (1), 7-26. 
Hillman, A. J., A. A. Cannella, and R. L. Paetzold, "The Resource Dependence Role of Corporate Directors: Strategic Adaptation of Board Composition in Response to Environmental Change," Journal of Management Studies, 2000, 37 (2), 235-256.

_, A. A. Cannella Jr., and I. C. Harris, "Women and Racial Minorities in the Boardroom: How Do Directors Differ?," Journal of Management, 2002, 28 (6), 747-763.

Jeanjean, T. and H. Stolowy, "Determinants of Board Members' Financial ExpertiseEmpirical Evidence from France," The International Journal of Accounting, 2009, 44 (4), 378-402.

KPMG, Corporate Governance in der Schweiz: Verwaltungsrat - Zwischen Verantwortung und Haftung, Zürich: KPMG Fides Management AG, 2001.

Kroszner, R. S. and P. E. Strahan, "Bankers on Boards: Monitoring, Conflicts of Interest, and Lender Liability," Journal of Financial Economics, 2001, 62 (3), 415-452.

La Porta, R., F. Lopez de Silanes, A. Shleifer, and R. Vishny, "Law and Finance," The Journal of Political Economy, 1998, 106 (6), 1113-1155.

Linck, J. S., J. M. Netter, and T. Yang, "The Effects and Unintended Consequences of the Sarbanes-Oxley Act on the Supply and Demand for Directors," Review of Financial Studies, 2009, 22 (8), 3287-3328.

Non, M. and P. H. Franses, "Interlocking Boards and Firm Performance: Evidence from a New Panel Database," Tinbergen Institute Discussion Paper No. 07-034/2, Tinbergen Institute, 2007.

Ramirez, C. D., "Did JP Morgan's Men Add Liquidity? Corporate Investment, Cash Flow, and Financial Structure at the Turn of the Twentieth Century," Journal of Finance, 1995,50 (2), 661-678.

RiskMetrics Groups, "Board Practices: Trends in Board Structure at S\&P 1'500 Companies," 2008.

Schletti, B., "Die Old Boys gehen — es lebe der neue Filz," Tages Anzeiger, 2006, March 6.

Schroder, Y. and A. Schrader, "The Changing Role of Banks and Corporate Governance in Germany: Evolution Towards the Market?,"Working Paper, American Institute for Contemporary German Studies, 1997.

SIX Exchange, "Directive on Information Relating to Corporate Governance,” 2008.

Spencer Stuart, "Board Index," 25th edition, 2010. 
White, H., "A Heteroskedasticity-Consistent Covariance Matrix Estimator and a Direct Test for Heteroskedasticity," Econometrica: Journal of the Econometric Society, 1980, $48(4), 817-838$.

Zeng, Z. and Y. Xie, "Asian Americans' Earnings Disadvantage Reexamined: The Role of Place of Education," The American Journal of Sociology, 2004, 109 (5), 1075-1108.

\section{.1 Indices}

\section{Herfindahl-Hirschmann Index}

The first concentration index is labeled Herfindahl-Hirschman Index (or Simpson, Blau, or Gibbs-Martin Index). This index is calculated as follows ( $p$ is the fraction of directors in the $i$-th group of a specific category (e.g., economists)):

$$
H H I=\sum_{i=1}^{N} p_{i}^{2}
$$

An index value of 1 implies that the board consists of one group with equal director's characteristics. The lower the value, the less homogeneous the board is.

\section{Shannon Index}

The second concentration index is labeled Shannon Index (or Entropy or Teachman Index): This index is calculated as follows ( $p$ is the fraction of directors in the $i$-th group of a specific category (e.g., economists)):

$$
S H I=-\sum_{i=1}^{N} p_{i} \times \ln \left(p_{i}\right)
$$

